\title{
Potential use of RNA-dependent RNA polymerase (RdRp) inhibitor against COVID-19 infection
}

\author{
Charles NS Allen 1, „, Sterling P Arjona 1, „, Maryline Santerre 1, Bassel E Sawaya 1, 2, 凤 \\ 1 Molecular Studies of Neurodegenerative Diseases Lab, FELS Institute, 2 Department of Neurology; Lewis Katz \\ School of Medicine - Temple University Philadelphia, PA 19140.
}

‡ Charles NS Allen and Sterling P Arjona contributed equally to this work. Author order was determined alphabetically.

ף Corresponding Author:

Bassel E Sawaya, PhD, MS(IME), MBA, Fels Institute for Cancer Research, Lewis Katz School of Medicine,

Temple University.

3307 North Broad Street;

Philadelphia, Pennsylvania 19140.

Phone: 215-707-5446;

Fax: 215-707-5948;

E-mail: sawaya@temple.edu 


\section{ABSTRACT}

Favipiravir, an inhibitor of RNA-dependent RNA polymerase used against the Japanese flu, was recently suggested as a potential COVID-19 inhibitor. Since Favipiravir targets a critical and a viral specific process, using it as a treatment could be beneficial in slowing the outbreak. Though there have been many suggested antivirals to treat SARS-CoV-2 infection, most treatments target host-associated pathways that may cause adverse effects, Favipiravir or similar combination may be the best remedy against COVID-19 pandemic. 


\section{INTRODUCTION}

Coronavirus Disease-2019 (COVID-19) is the disease caused by the novel severe acute respiratory syndrome-coronavirus 2 (SARS-CoV-2). SARS-CoV-2 is a member of the coronavirus family recently discovered in Wuhan, Hubei, China. The coronavirus family was initially discovered in the later part of the 1960s. Since the discovery there have been several members of this virus that have caused serious respiratory tract infections, these include Severe Acute Respiratory Syndrome (SARS-CoV) in 2003, Middle East Respiratory Syndrome (MERS-CoV) in 2012, and the current outbreak SARS-CoV-2 (previously known as 2019-nCoV).

Coronaviruses (CoVs) belong to the Nidovirales order and got their names from the unique "crownlike" spikes that are visible on the outer membrane of the virions. Coronaviruses are large singlestranded, enveloped RNA viruses that are broken down into four classes: Alphacoronavirus, Betacoronavirus, Gammacoronavirus, and Deltacoronavirus. Coronaviruses are the largest RNA viruses known with a genome ranging between 27 and $32 \mathrm{~kb}$ (1). Like all the Nidovirales members, Coronaviruses have a highly conserved genomic organization, unique enzymatic activities, and expression of nonstructural genes by ribosomal frameshifting.

Since the initial infection of SARS-CoV-2 in Wuhan the virus has spread globally. Although the mortality rate of COVID-19 is comparatively lower than previous coronavirus outbreaks (SARS-CoV$10 \%$ and MERS-CoV- 37\%), it is much higher than the 2018-2019 influenza season (0.96\%). The first case in the United States was confirmed on January 20, 2020 in Washington State and has since spread to every states and territories. This outbreak has been devastating to older population (over 60 ) which

are at higher risk and show more severe symptoms when compared with younger population. As with other coronaviruses, SARS-CoV-2 infects the lung epithelial cells of the alveola and can lead to severe complications including pneumonia (2). COVID-19 has caused a global shut down of commerce and normalcy with governments calling for social distancing and even lockdown of entire cities and countries. It is thus important for the discovery of treatments for this novel virus to slow the outbreak and shorten the disease. 
SARS-CoV-2 is an enveloped single-stranded positive-sense RNA virus composed of four structural proteins, envelope $(\mathrm{E})$, membrane $(\mathrm{M})$, spike $(\mathrm{S})$, and nuclear capsid $(\mathrm{N})(3)$ (Figure 1). In addition to the structural proteins, the genome contains a 5' cap structure along with a 3 ' poly (A) tail that acts as a mRNA for translation of the replicase polyproteins. The replicase gene encodes the nonstructural proteins (NSPS) that form two-thirds of the genome. The genome also include several accessory proteins that are not essential for viral replication but were shown to play a role in viral pathogenesis.

Even though, the E protein is not conserved between coronaviruses, however it is important for assembly and release of the virus. The $M$ protein gives the virion its spherical shape and is the most abundant protein. The S protein has been shown to be important in host cell interactions and virulence (4). The N protein binds to the single-strand RNA inside the capsid to protect it in a beads-on-a-string conformation. SARS-CoV-2 differs from other coronaviruses because of its S protein. The S1 domain of the S protein has been shown to have a $45 \%$ difference in the amino acid sequence compared to that of SARS-CoV.

It has been found that the virus enters the body via droplets that travel to the respiratory tract, where it can infect cells containing angiotensin-converting enzyme 2 (ACE2) including lung epithelial cells (5). The S1 domain of the S protein has been shown to interact with ACE2 on the surface of cells (4). The S protein has also been predicted to interact with the Glucose Regulated Protein 78 (GRP78) (6). After binding to a receptor on the cell surface, the S protein is cleaved by a cellular protease: cathepsin (7) or TMPRSS2 (8) to expose the fusion peptide allowing the viral membrane to fuse with the cellular membrane. The viral genome is then released into the cytoplasm. Next, the host ribosomes translate the viral positive-sense RNA into 16 non-structural proteins (NSPS) (Table 1) (3). Some of these NSPS are involved in ensuring viral RNA is translated efficiently without host interference. Other NSPS are important for producing mature virions. The rest of the NSPS make the replicase-transcriptase complex (RTC). The RTC is composed of proteins that are required to replicate viral RNA both genomic and subgenomic through anti-sense RNA intermediates (3).

After viral genomic RNA replication and viral protein translation from sub-genomic RNA, the viral structural proteins are inserted into the endoplasmic reticulum (ER). After this insertion, the proteins 
follow the secretory pathway and form the endoplasmic reticulum-Golgi intermediate compartment (ERGIC) (8). Once the ERGIC is formed the viral RNA genomes, which are encapsulated by the $\mathrm{N}$ protein, are incorporated into the ERGIC which then buds into mature virions. The mature virions exit the cell via exocytosis and can infect other cells or be spread to other hosts.

\section{VIRAL RNA REPLICATION AS A THERAPEUTIC TARGET}

Currently, clinicians can only treat the various symptoms of COVID-19 because there is no targeted treatment for the SARS-CoV-2. Nevertheless, drugs used to treat Malaria and HIV-1 such as Chloroquine and Lopinavir/ritonavir, respectively, have been shown to possibly influence SARS-CoV-2 replication. Table 2 summarizes all the potential drugs that are in stage of development and the names of the pharmaceutical companies developing these drugs. Additional companies and schools launched studies aiming to develop new COVID-19 drugs/vaccine such as Pfizer, Enata Pharmaceutical, Integral Molecular, Takeda Pharmaceutical Company, Hong Kong University of Science and Technology, Columbia University, Tulane University and others (clinicaltrialsarena.com/ analysis/coronavirus-merscov-drugs/).

Chloroquine has been shown to inhibit the glycosylation of ACE2 and thus prevent SARS-CoV-2 from binding to cells. Studies revealed no cytotoxicity in vitro, however the glycosylation of ACE2 is important in the regulation of the renin-angiotensin system (9). Deregulation of this system could cause some adverse effects.

Similarly, Lopinavir/ritonavir is a protease inhibitor that could block the cleavage of the S protein of SARS-CoV-2 thus preventing fusion of the viral and cellular membranes (10). However, there are many known adverse effects of this drug and it has shown no significant improvements over standard care in treating COVID-19.

Ideally, it is better to target a step of the virus life cycle preventing it from forming mature virions and infecting other cells without damaging host cell function that could cause adverse side-effects. In order to reduce adverse effects, viral-specific processes can be inhibited or reversed. SARS-CoV-2 relies on host cellular mechanisms to reproduce mature virions. However, RNA replication from an RNA template is unique to the virus thus making this step a possible therapeutic target. Inhibiting the virus at the RNA 
replication step would result in 1) no genomic RNA replication, 2) no subgenomic replication and subsequent structural protein production, and 3) no mature virion formation and release essentially stopping the productive infection. By only targeting the RNA replication of the virus, NSPS can still be produced at low levels inside the cell but infection would end there. A possible drug candidate that inhibits the RNA-dependent RNA polymerase (RdRp) and would result in the inhibition of SARS-CoV2 is Favipiravir.

\section{FAVIPIRAVIR}

Favipiravir (6-fluoro-3-hydroxy-2-pyrazinecarboxamide) also known as T-705, Avigan or Favilavir, is an antiviral agent that was first developed by Toyama Chemical Co. against the Japanese flu (11). Favipiravir is a pyrazinecarboxamide derivative that can inhibit the $R d R p$ of influenza virus and was also shown to have antiviral activities beyond Japanese flu. In animals, Favipiravir has shown activity against viruses such as Influenza, West Nile, Yellow fever, Foot and Mouth Disease, and Rift Valley as well as other Flaviviruses, Arenaviruses, Bunyaviruses, Alphaviruses (e.g. Chikungunya [CHIKV]; Sindbis [SINV]; Western equine encephalitis [WEEV]; and Semliki Forest [SFV] viruses), and Enteroviruses (12-14). Favipiravir was also shown to have an effect in vitro and in vivo against Zaire Ebola (15), Rabies (RABV) (16) and Zika viruses (17). Favipiravir was escribed to reduce the morbidity and mortality associated with RABV infection in mice. In Syrian hamster model that mirrors the human disease, Favipiravir reduced encephalitis, hemorrhagic fever, respiratory difficulties and mortality rate caused by Nipah virus infection (a Bat virus) (18).

Favipiravir is structurally similar to Ribavirin (antiviral drug used to treat Respiratory Syncytial Virus [RSV] infection, Hepatitis C and some viral hemorrhagic fevers) (19). Favipiravir and Ribavirin share a carboxamide $\left(\mathrm{C}-[\mathrm{O}]-\mathrm{NH}_{2}\right)$ moiety, however Favipiravir is a more specific version of Ribavirin. Both drugs target the viral RNA polymerase, Ribavirin primarily targets the Inosine-5'-monophosphate dehydrogenase (IMPDH), while Favipiravir interacts with RNA polymerase.

Mechanistically, Favipiravir and its form Favipiravir-RMP (favipiravir-ribofuranosyl-50monophosphate) do not inhibit influenza RNA polymerase activity, but it is the phosphoribosylated form, favipiravir-ribofuranosyl-50-triphosphate (Favipiravir-RTP) that inhibits the enzyme. It has been 
suggested that the human hypoxanthine guanine phosphoribosyl-transferase (HGPRT) plays a role in the Favipiravir activation (20). The active form of Favipiravir is recognized by the catalytic domain of the viral RNA-dependent RNA polymerase and blocks its enzymatic activity. This results in inhibition of the RNA-dependent RNA polymerase and effectively ending the infectious cycle of SARS-CoV-2 (Figure 2). Note that Favipiravir is not toxic to mammalian cells and does not inhibit RNA or DNA synthesis within these cells.

All these features make Favipiravir a broad-spectrum inhibitor of RdRp, the polymerase responsible for replicating RNA and the major functional unit of the RTC in SARS-CoV2 making this drug the best available drug to fight the spread of COVID-19.

Currently, Favipiravir has been approved in Japan as an influenza treatment (Japanese flu), while awaiting approval in the USA after successfully passing phase III clinical trials. Favipiravir has been shown to be an efficient treatment against COVID-19 in Wuhan, China . Even though, the study lacks controls (double blinded, placebo), however Favipiravir has been shown to reduce viral clearance time in 80 patients to 4 days compared to 11 days for the control group, and that $91.43 \%$ of patients had improved CT scans with few side effect. These results encouraged other countries such as Turkey to start using Favipiravir as a potential treatment against COVID-19.

\section{CONCLUSION AND FUTURE DIRECTIONS}

COVID-19 caused by the novel coronavirus, SARS-CoV-2, is currently spreading quickly across the globe. Favipiravir is an ideal targeted treatment since it is viral-specific and has already been used in clinical trials including a Phase 3 trial for the treatment of Japanese influenza. Favipiravir targets and blocks viral RNA-dependent RNA polymerase $(\mathrm{RdRp})$ that is used by the virus to replicate and produce mature virions. Blocking this step in the viral life cycle won't prevent infection but will shorten the duration and reduce the severity. It may also shorten the time a patient is contagious. Clinical trials need to be completed to further explore the possibility of Favipiravir as an effective treatment for the spread and severity of SARS-CoV-2, but the previous research seems promising that Favipiravir could be a useful treatment. 
In conclusion, Favipiravir has great potential to be effective in treating COVID-19 and should be fast-tracked into clinical trials in the US. A drug like Favipiravir that can shorten infection will help to reduce the number of fatalities that SARS-CoV-2 is estimated to cause in the near future.

\section{ACKNOWLEDGMENTS}

This work is supported by an NIH-NIA (R01-AG054411) awarded to BES. 


\section{REFERENCES}

1. Perlman S, Netland J. 2009. Coronaviruses post-SARS: update on replication and pathogenesis. Nat Rev Microbiol 7:439-450.

2. Zhou P, Yang X-L, Wang X-G, Hu B, Zhang L, Zhang W, Si H-R, Zhu Y, Li B, Huang C-L, Chen HD, Chen J, Luo Y, Guo H, Jiang R-D, Liu M-Q, Chen Y, Shen X-R, Wang X, Zheng X-S, Zhao K, Chen Q-J, Deng F, Liu L-L, Yan B, Zhan F-X, Wang Y-Y, Xiao G-F, Shi Z-L. 2020. A pneumonia outbreak associated with a new coronavirus of probable bat origin. Nature 579:270-273.

3. Chen Y, Liu Q, Guo D. 2020. Emerging coronaviruses: Genome structure, replication, and pathogenesis. J Med Virol 92:418-423.

4. Yan R, Zhang Y, Li Y, Xia L, Guo Y, Zhou Q. 2020. Structural basis for the recognition of the SARSCoV-2 by full-length human ACE2. Science pii: eabb2762.

5. Li G, Fan Y, Lai Y, Han T, Li Z, Zhou P, Pan P, Wang W, Hu D, Liu X, Zhang Q, Wu J. 2020. Coronavirus infections and immune responses. J Med Virol 92:424-432.

6. Ibrahim IM, Abdelmalek DH, Elshahat ME, Elfiky AA. 2020. COVID-19 spike-host cell receptor GRP78 binding site prediction. J Infect pii: S0163-4453(20)30107-9.

7. Fehr AR, Perlman S. 2015. Coronaviruses: An Overview of Their Replication and Pathogenesis. Methods Mol Biol 1282:1-23.

8. Hoffmann M, Kleine-Weber H, Schroeder S, Krüger N, Herrler T, Erichsen S, Schiergens TS, Herrler G, Wu N-H, Nitsche A, Müller MA, Drosten C, Pöhlmann S. 2020. SARS-CoV-2 Cell Entry Depends on ACE2 and TMPRSS2 and Is Blocked by a Clinically Proven Protease Inhibitor. Cell pii: S00928674(20)30229-4.

9. Warner FJ, Lew RA, Smith Al, Lambert DW, Hooper NM, Turner AJ. 2005. Angiotensin-converting Enzyme 2 (ACE2), But Not ACE, Is Preferentially Localized to the Apical Surface of Polarized Kidney Cells. J Biol Chem 280:39353-39362.

10. Cao B, Wang Y, Wen D, Liu W, Wang J, Fan G, Ruan L, Song B, Cai Y, Wei M, Li X, Xia J, Chen $\mathrm{N}$, Xiang J, Yu T, Bai T, Xie X, Zhang L, Li C, Yuan Y, Chen H, Li H, Huang H, Tu S, Gong F, Liu Y, Wei Y, Dong C, Zhou F, Gu X, Xu J, Liu Z, Zhang Y, Li H, Shang L, Wang K, Li K, Zhou X, Dong X, Qu Z, Lu S, Hu X, Ruan S, Luo S, Wu J, Peng L, Cheng F, Pan L, Zou J, Jia C, Wang J, Liu X, Wang S, Wu X, Ge Q, He J, Zhan H, Qiu F, Guo L, Huang C, Jaki T, Hayden FG, Horby PW, Zhang D, Wang C. 2020. A Trial of Lopinavir-Ritonavir in Adults Hospitalized with Severe Covid-19. N Engl J Med. doi: 10.1056/NEJMoa2001282.

11. Furuta $Y$, Takahashi K, Fukuda $Y$, Kuno M, Kamiyama T, Kozaki K, Nomura N, Egawa H, Minami $\mathrm{S}$, Watanabe $\mathrm{Y}$, Narita $\mathrm{H}$, Shiraki K. 2002. In vitro and in vivo activities of anti-influenza virus compound T-705. Antimicrob Agents Chemother 46:977-981.

12. Furuta Y, Takahashi K, Shiraki K, Sakamoto K, Smee DF, Barnard DL, Gowen BB, Julander JG, Morrey JD. 2009. T-705 (favipiravir) and related compounds: Novel broad-spectrum inhibitors of RNA viral infections. Antiviral Res 82:95-102.

13. Furuta Y, Gowen BB, Takahashi K, Shiraki K, Smee DF, Barnard DL. 2013. Favipiravir (T-705), a novel viral RNA polymerase inhibitor. Antiviral Res 100:446-454. 
14. Caroline AL, Powell DS, Bethel LM, Oury TD, Reed DS, Hartman AL. 2014. Broad Spectrum Antiviral Activity of Favipiravir (T-705): Protection from Highly Lethal Inhalational Rift Valley Fever. PLoS Negl Trop Dis. 8:e2790.

15. Kerber R, Lorenz E, Duraffour S, Sissoko D, Rudolf M, Jaeger A, Cisse SD, Camara AM, Miranda O, Castro CM, Akoi Bore J, Raymond Koundouno F, Repits J, Afrough B, Becker-Ziaja B, Hinzmann J, Mertens M, Vitoriano I, Hugh Logue C, Böttcher JP, Pallasch E, Sachse A, Bah A, CabezaCabrerizo M, Nitzsche K, Kuisma E, Michel J, Holm T, Zekeng EG, Cowley LA, Garcia-Dorival I, Hetzelt N, Baum JHJ, Portmann J, Carter L, Yenamaberhan RL, Camino A, Enkirch T, Singethan K, Meisel S, Mazzarelli A, Kosgei A, Kafetzopoulou L, Rickett NY, Patrono LV, Ghebreghiorghis L, Arnold U, Colin G, Juchet S, Marchal CL, Kolie JS, Beavogui AH, Wurr S, Bockholt S, Krumkamp R, May J, Stoecker K, Fleischmann E, Ippolito G, Carroll MW, Koivogui L, Magassouba N, Keita S, Gurry C, Drury P, Diallo B, Formenty P, Wölfel R, Di Caro A, Gabriel M, Anglaret X, Malvy D, Günther S. 2019. Laboratory Findings, Compassionate Use of Favipiravir, and Outcome in Patients With Ebola Virus Disease, Guinea, 2015-A Retrospective Observational Study. J Infect Dis 220:195-202.

16. Yamada K, Noguchi K, Komeno T, Furuta Y, Nishizono A. 2015. Efficacy of Favipiravir (T-705) in Rabies Postexposure Prophylaxis. J Infect Dis 213:1253-1261.

17. Cai L, Sun Y, Song Y, Xu L, Bei Z, Zhang D, Dou Y, Wang H. 2017. Viral polymerase inhibitors T705 and T-1105 are potential inhibitors of Zika virus replication. Arch Virol 162:2847-2853.

18. Dawes BE, Kalveram B, Ikegami T, Juelich T, Smith JK, Zhang L, Park A, Lee B, Komeno T, Furuta Y, Freiberg AN. 2018. Favipiravir (T-705) protects against Nipah virus infection in the hamster model. Sci Rep 8:7604.

19. Drabikowska AK, Dudycz L, Shugar D. 1979. Studies on the mechanism of antiviral action of 1 (beta-D-ribofuranosyl)-1,2,4-triazole-3-carboxamide (ribavirin). J Med Chem 22:653-657.

20. Naesens L, Guddat LW, Keough DT, van Kuilenburg AB, Meijer J, Vande Voorde J, Balzarini J. 2013. Role of human hypoxanthine guanine phosphoribosyltransferase in activation of the antiviral agent T-705 (favipiravir). Mol Pharmac 84:615-629. 


\section{FIGURES LEGENDS}

Figure 1. Schematic presentation of the COVID-19 structure. Structural Proteins of SARS-CoV 2 where the location and names of the viral proteins are shown $(S=$ spike; $N=$ nucleocapside; $M=$ membrane; E= Envelope). Structure was created using Biorender software.

Figure 2. Favipiravir Mechanism of Action. Numbers in black indicate the normal life cycle of SARSCoV2 from 1) binding to ACE2 receptors and then fusion with the cellular membrane, 2) release of the viral genome in the form of $(+)$ sense RNA and the subsequent production of non-structural proteins (NSPS), 3) translation and formation of the replicase-transcriptase complex (RTC), 4) RNA replication of genomic and subgenomic RNA, 5) transcription of subgenomic RNA, 6) translation of that RNA into structural proteins, 7) nucleocapsid combination with S, E, and M proteins in the ERGIC, 8) budding of the ERGIC into a mature virion, and 9) exocytosis of mature virions. Numbers in red indicate the mechanism of action of Favipiravir from 1) entry into the cell in the inactive form, 2) converted to active form by phosphoribosylation, and 3) binding to RNA-dependent RNA polymerase to block its active site.

Table 1. List of viral NSPS and their known functions.

Table 2. List of Potential or in development drugs, pharmaceutical companies and mechanisms of action. Yellow shaded- drugs developed to treat different diseases but was used to treat COVID-19; White shaded- names of major drugs/vaccine that have the potential to become drugs in various stage of development; Light Green shaded- drugs in various stages of development globally. 


\section{FIGURE 1}



\section{FIGURE 2}

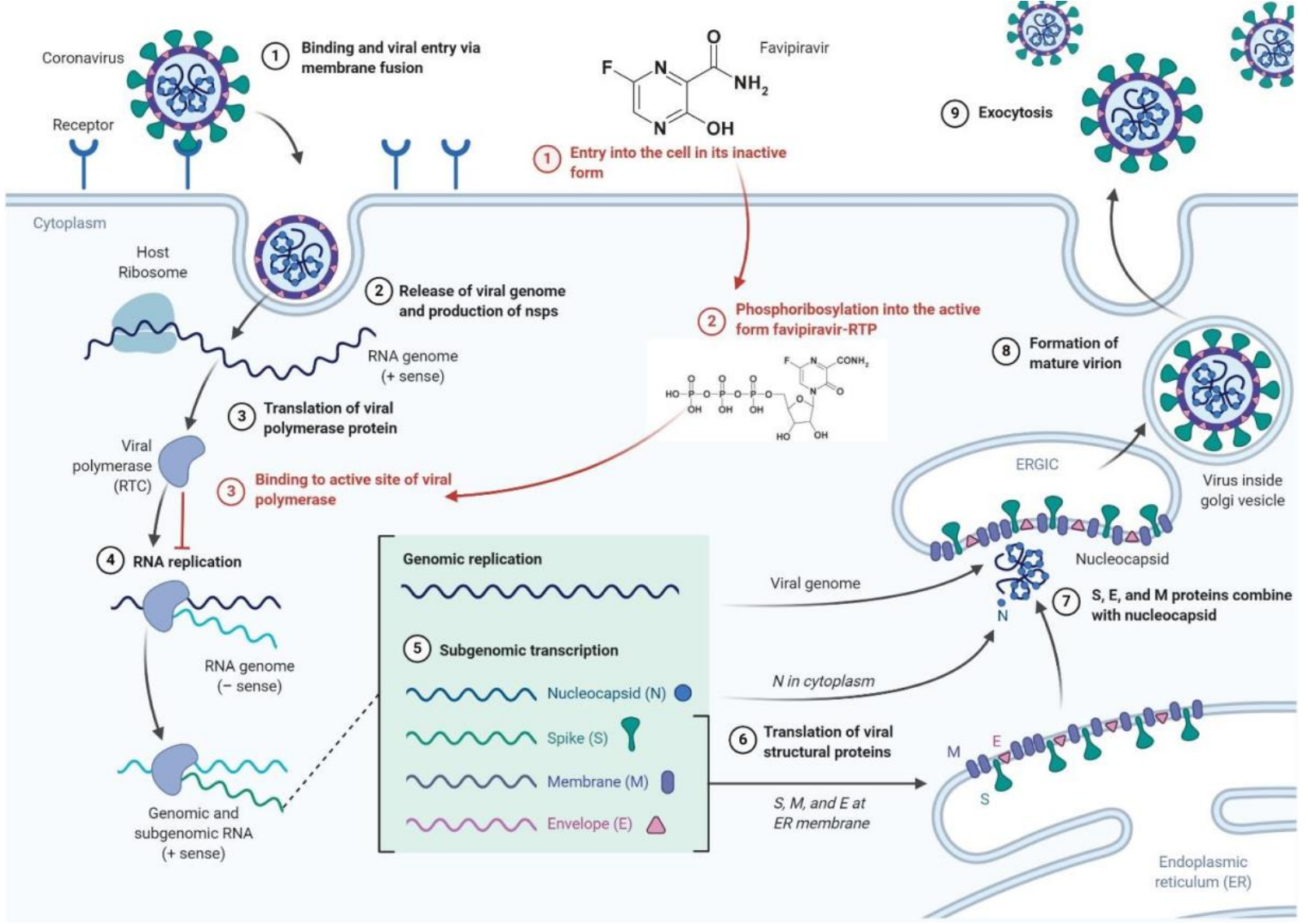


TABLE 1

\begin{tabular}{|l|l|}
\hline \multicolumn{1}{|c|}{ Protein } & \multicolumn{1}{c|}{ Function(s) } \\
\hline nsp1 & Causes degradation of Host cell mRNA \\
\hline nsp2 & Function currently unknown \\
\hline nsp3 & $\begin{array}{l}\text { Multi-domain transmembrane protein which interacts with the viral N protein, promotes } \\
\text { cytokine expression, cleaves viral polypeptides, and blocks host innate immunity }\end{array}$ \\
\hline nsp4 & Transmembrane protein that is important for double-membrane vesicle (DMV) formation \\
\hline nsp5 & Cleaves viral polyproteins \\
\hline nsp6 & Transmembrane protein \\
\hline nsp7 & One part of the RNA polymerase clamp \\
\hline nsp8 & One part of the RNA polymerase clamp, possible primase \\
\hline nsp9 & RNA binding protein \\
\hline nsp10 & nsp14 and nsp16 cofactor \\
\hline nsp11 & Function currently unknown \\
\hline$n s p 12 ~$ & RNA dependent RNA polymerase \\
\hline$n s p 13$ & RNA helicase \\
\hline$n s p 14$ & MTase and exoribonuclease \\
\hline$n s p 15$ & Viral endoribonuclease \\
\hline nsp16 & Protects viral RNA \\
\hline
\end{tabular}


TABLE 2

\begin{tabular}{|c|c|c|}
\hline Name & Company & Targets/Mechanisms \\
\hline Chloroquine & SANOFI & Malaria /Arthritis \\
\hline Favipiravir & Toyama Chemical & Japanese Flu \\
\hline TJM2 & I-Mab Biopharma & $\begin{array}{l}\text { Targets GM-CSF (responsible for acute or chronic } \\
\text { inflammation) }\end{array}$ \\
\hline No name & $\begin{array}{l}\text { Medicago and Laval } \\
\text { University's Infectious Disease } \\
\text { Research Centre }\end{array}$ & Virus-Like Particles (VLP) of the coronavirus \\
\hline AT-100 (rhSP-D) & Airway Therapeutics / NIH & $\begin{array}{l}\text { Reduces inflammation and infection in the lungs; Generates } \\
\text { an immune response against various respiratory diseases }\end{array}$ \\
\hline TZLS-501 & Tiziana Life Sciences & $\begin{array}{l}\text { Anti-interleukin- } 6 \text { receptor; } \\
\text { Prevents lung damage and elevated levels of IL- } 6\end{array}$ \\
\hline OYA1 & OyaGen & Prevents viral replication in cell culture \\
\hline BPI-002 & BeyondSpring & $\begin{array}{l}\text { Small molecule, activates CD4+ helper T cells and CD8+ } \\
\text { cytotoxic T cells; } \\
\text { Generates an immune response in the body }\end{array}$ \\
\hline Intranasal vaccine & Altimmune & Similar to NasoVAX, an influenza vaccine \\
\hline INO-4800 & $\begin{array}{l}\text { Inovio Pharmaceuticals/ } \\
\text { Beijing Advaccine } \\
\text { Biotechnology }\end{array}$ & $\begin{array}{l}\text { Activates immune system to generate a robust targeted } \mathrm{T} \\
\text { cell and antibody response }\end{array}$ \\
\hline NP-120 (Ifenprodil) & Algernon Pharmaceuticals & $\begin{array}{l}\text { N-methyl-d-aspartate (NDMA) receptor } \\
\text { Glutamate receptor antagonist }\end{array}$ \\
\hline mRNA-1273 vaccine & $\begin{array}{l}\text { Moderna and Vaccine } \\
\text { Research Center-NIAID }\end{array}$ & Targets the Spike (S) protein of the coronavirus \\
\hline APN01 & $\begin{array}{l}\text { University of British Columbia } \\
\text { and APEIRON Biologics }\end{array}$ & Targets ACE2 in SARS \\
\hline $\begin{array}{l}\text { Avian Coronavirus } \\
\text { Infectious Bronchitis } \\
\text { Virus (IBV) vaccine }\end{array}$ & MIGAL Research Institute & $\begin{array}{l}\text { Treats avian coronavirus; } \\
\text { Modified to treat COVID-19 }\end{array}$ \\
\hline TNX-1800 & $\begin{array}{l}\text { Tonix Pharmaceuticals and } \\
\text { Southern Research }\end{array}$ & $\begin{array}{l}\text { Modified Horsepox virus designed to express a protein } \\
\text { derived from the virus that causes the coronavirus infection }\end{array}$ \\
\hline Brilacidin & Innovation Pharmaceuticals & $\begin{array}{l}\text { Antibacterial, anti-inflammatory and immunomodulatory } \\
\text { properties }\end{array}$ \\
\hline $\begin{array}{l}\text { Oral recombinant } \\
\text { vaccine }\end{array}$ & Vaxart & No Info \\
\hline $\begin{array}{l}\text { Recombinant subunit } \\
\text { vaccine }\end{array}$ & Clover Biopharmaceuticals & $\begin{array}{l}\text { Targets the trimeric S protein (S-Trimer) of the COVID-19 } \\
\text { (responsible for binding with the host cell and causing a viral } \\
\text { infection) }\end{array}$ \\
\hline Leronlimab (PRO 140) & CytoDyn & CCR5 antagonist \\
\hline Linear DNA Vaccine & $\begin{array}{l}\text { Applied DNA Sciences and } \\
\text { Takis Biotech }\end{array}$ & No Info \\
\hline BXT-25 & BIOXYTRAN & Supplies oxygen to the vital organs \\
\hline MERS vaccine & Novavax & Binds to the major surface S-protein \\
\hline AmnioBoost & Lattice Biologics & $\begin{array}{l}\text { Reduces the production of pro-inflammatory cytokines while } \\
\text { boosting the production of anti-inflammatory cytokines }\end{array}$ \\
\hline SNG001 & Synairgen Research & $\begin{array}{l}\text { An interferon- } \beta \text {, which is delivered directly to the lungs to } \\
\text { reduce the infection }\end{array}$ \\
\hline $\begin{array}{l}\text { REGN3048/51 and } \\
\text { Kevzara }\end{array}$ & Regeneron & $\begin{array}{l}\text { Both antibodies bind to S-protein of MERS coronavirus; } \\
\text { Kevzara blocks interleukin-6 pathway }\end{array}$ \\
\hline Galidesivir (BCX4430) & Biocryst Pharma & Nucleoside RNA polymerase inhibitor \\
\hline Actemra & Roche & $\begin{array}{l}\text { Prevents cytokine storms or overreaction of the immune } \\
\text { system }\end{array}$ \\
\hline Remdesivir (GS-5734) & Gilead Sciences & Developed against Ebola but ineffective \\
\hline
\end{tabular}

